\title{
The oral administration of bacterial extracts prevents asthma via the recruitment of regulatory T cells to the airways
}

\author{
Nicolas Glaichenhaus ${ }^{1,2^{*}}$, Valérie Julia ${ }^{1,2}$ \\ From 6th European Workshop on Immune-Mediated Inflammatory Diseases \\ Nice, France. 23-25 November 2011
}

\section{Background}

The prevalence of asthma has steadily increased during the last decade, probably as the result of changes in the environment, including reduced microbial exposure during infancy. Accordingly, experimental studies have shown that deliberate infections with live pathogens prevent the development of allergic airway diseases in mice. Bacterial extracts are currently used in children suffering from repeated upper respiratory tract infections. In this study, we have investigated whether bacterial extracts, commercially available as Broncho-Vaxom (BV), could prevent allergic airway disease in mice.

\section{Results}

Oral treatment with BV suppressed airway inflammation through IL-10-dependent and MyD88-dependent mechanisms and induced the conversion of FoxP3-negative T cells into FoxP3-positive regulatory $\mathrm{T}$ cells. Furthermore, CD4positive $\mathrm{T}$ cells purified from the trachea of BV-treated mice conferred protection against airway inflammation when adoptively transferred into sensitized mice.

\section{Conclusion}

Treatment with BV could possibly be a safe and efficient strategy to prevent the development of allergic disease in children.

\section{Author details}

${ }^{1}$ Université de Nice-Sophia Antipolis, Institut National de la Santé et de la Recherche Médicale, Valbonne, France. ${ }^{2}$ Université de Lille 2, Institut National de la Santé et de la Recherche Médicale, Lille, France.

${ }^{1}$ Université de Nice-Sophia Antipolis, Institut National de la Santé et de la Recherche Médicale, Valbonne, France

Full list of author information is available at the end of the article
Published: 23 November 2011

doi:10.1186/1479-5876-9-S2-P22

Cite this article as: Glaichenhaus and Julia: The oral administration of bacterial extracts prevents asthma via the recruitment of regulatory $T$ cells to the airways. Journal of Translational Medicine 2011 9(Suppl 2):P22.
Submit your next manuscript to BioMed Central and take full advantage of:

- Convenient online submission

- Thorough peer review

- No space constraints or color figure charges

- Immediate publication on acceptance

- Inclusion in PubMed, CAS, Scopus and Google Scholar

- Research which is freely available for redistribution

\section{Biomed Central}

